\title{
Communication Activities Seba Baduy Lebak Regency Banten
}

\section{Ali Syamsuddin Amin}

Lecturer Communication Department, Majalengka University, Indonesia m.ali.syamsudin@gmail.com
Keywords

SebaBaduy, activity communication: communicationethnographic subs such as communicative situation, communicative event and communicative act in Seba Baduy ceremony, Lebak Banten Region. The Applied method for the project is qualitative method of communication Ethnographic. The subject of the research is Baduy and Jaro Luar community which follows Seba Baduy ceremony, there are 3 informants obtained by purposive technique in the researched ceremony. The data gathering requirement held through in-depth interview, non-participant observation, field notes, literature study, documentations and daring searching. The technique of testing the validity of data by increasing the persistence of observation, triangulation and discussion among friends. For the analytical data used are descriptive, analytical, and interpretation. Research result shows that communicative situation found in the Seba Baduy ceremony which held on two spots Pendopo of Lebak Region and Pendopo of Banten Province on Safar month. Communicative event in the Seba Baduy ceremony as the gratitude and do what the ancestors of Baduy community have passed through generations. While communicative acts in Seba Baduy is act which shows verbal and non-verbal acts as respect expression for the Government and appreciate the nature.

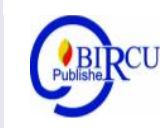

\section{Introduction}

Seba Baduy is one of the activities or traditions that Baduy people do in grateful for the harvest in one year. The traditional celebration of Seba, according to the people of Baduy, is a relic of the Elder ancestors (Kokolot) that must be performed once in each year. The event was held after the harvest season of the Huma field, even tradition has lasted hundreds of years since the era of Banten Sultanate in Serang Regency. However, in the Seba ceremony this time, it is done in 2 (two) places in the Lebak Regency city hall and provincial city hall. Seba itself is giving up the crops or produce of the Earth to the local government that we commonly call a tribute to the kingdom but different from the tribute. It is all the gratitude of the outer Baduy people and Baduy in because it gets abundant harvest, this Seba activity without any compulsion from any outside Baduy community led by Jaro or Baduy in led by Puun, Together brought the crops to the government that was handed over to the Regent Lebak directly at the city hall of Lebak Regency.

Seba Baduy activities must be carried out on foot from the village where they live to the center of Lebak Regency precisely in the city hall of Lebak Regency. Baduy people are not allowed to use vehicles or footwear on their way. Seba Baduy's activities are carried out by all the Baduy people, both residing in the inner Baduy and outer Baduy. The purpose and 
objectives of this Seba Baduy activity as a tribute to the existing government because it has been allowed to occupy a territory that does not belong to Baduy people other than that Seba event was conducted to carry out what has been ordered by Their ancestors as gratitude to the God Almighty. Broadly, the ceremony of Seba Baduy begins with walking distance from his residence to the center of the government after it is doing with mutual prayer. Baduy people believe that by doing this activity the harvest of the next year can be more abundant and much better.

Researchers, in this case, are interested in knowing more about the Seba Baduy activities that are still carried out by all Baduy tribe communities, because today we are all in the era of modernization with all its negative and positive aspects, but there are still groups of people who still uphold customary law and still carrying out traditional activities which are considered by some people to be unfavorable in religious teachings, which is Islam. The Baduy people in their lives are guided by the traditions that their ancestors inherited. They adhere to the values, norms, knowledge, and rules that are undertaken as a belief that when violating the tradition is believed to meet disasters, then the series of activities of Seba Baduy are always the same and never change in the implementation. As a social creature of the life of Baduy people in running Seba Baduy activities cannot be removed from communication activities, because communication is an important part of human social life or society. According to Dell Hymes quoted in Engkus Kuswarno's book, communication activity is a typical or complex activity in which there are typical events of communication involving certain acts of communication and in certain contexts as well (Kuswarno, 2008: 42). With a description of the communication ethnography by Dell Hymes in the book Engkus Kuswarno, to obtain a clear and comprehensive picture. It is divided into several sub-focal ethnographic communications, namely communicative situations, communicative events and communicative actions. As for the ethnographic explanation of communication in the book Engkus Kuswarno, the focus of attention is the behavior of communication in certain cultural themes. The means of communication according to communication science is the action or activity of a person, group or audience when involved in the communication process (Kuswarno, 2008: 35). In the Book of Engkus Kuswarno, ethnographic communication sees the behavior of communication as the behavior born of the integration of three skills possessed by each individual as a social creature, the three skills it comprises of linguistic skills, interaction skills, and cultural skills (Kuswarno, 2008: 18).

The communicative situation is a general setting, the setting is defined as the size of space and time and arrangement. In Communicative situation there is communication contains the process of delivering messages by someone to other people to tell, change attitudes, opinions or behavior either directly orally or indirectly through the media (Hasbullah, 2018). The size of the space or setup of a room is necessary for an event to occur. Based on the pre-study Ritual Procession of Seba is done in several places, the office of Regent Lebak-Banten, office of Banten governor. Communicative events are the basic unit of descriptive purpose. A particular event is defined as the entire unit of component intact. Starting from the general purpose of communication, the same general topic, the same participants, the same common language varieties, the same tone, the same rules for interacting in the same settings. Conceptually, based on the pre-research process, the ritual ceremony starts from the mandate of their ancestors who are obliged to carry out the pikukuh. Communicative actions can be predicted to include exclamation, praise, self-esteem, gratitude, and command. Based on pre-research in the ritual procession, Seba is led by Jaro Tangtu or governance Jaro. In this case, Jaro ordered the harvest to be brought to the Banten 
government. If the harvest is not used then this ritual is not perfect. The importance of subfocus is a reference researcher for his research that is to describe deeply and describe in-depth about the activities of the Seba Baduy ceremony that became research material. Sub-Focus is a tool to dissect the events that are thoroughly so that researchers can find out about what is in the activities that are thorough.

Based on the explanation above, the researcher considers Seba Baduy activity which is implemented by people of Ciboleger village Baduy Tribe Lewidamar Regency, LebakBanten Regency is a culture that has its own meaning for Baduy tribe community. Researchers want to reveal the meaning of the cultural ceremony and see how the process of communication activity occurs in it. The culture or activity of Seba Baduy Lebak Banten, when viewed using the communication ethnography approach will explain every detail of the tradition.

\section{Research Method}

The method used in this research is a qualitative method, with a tradition of communication ethnography, the substantive theory adopted which is symbolic interaction and symbolic convergence, in which to analyze the communication activity of the traditional event of Seba Baduy Lebak Regency of Banten. The understanding of communication activity according to Hymes quoted in Engkus Kuswarno is a complex characteristic activity, in which there are special events that involve certain communication acts and in the context of certain communication (Kuswarno, 2008: 42). So if qualitative research is observed in it there is an inductive thought process in understanding and interpreting a phenomenon that occurs using a natural method. The ethnographic approach that exists in qualitative research also does not escape the field of anthropology that contains linguistic values and communication. According to Frey et al. in the book Deddy Mulyana that ethnography was used to examine human behavior in a specific natural environment (Mulyana,2008: 161). The combination of ethnography and communication will eventually bring about the typical research. Communication ethnography is very relevant in the realm of qualitative research methods, this is because in qualitative research will lead communication ethnography to understand how language, communication, and culture cooperated with each other to produce distinctive behavior. The ethnographic talk does not escape the study of anthropology and sociolinguistics, in comparison with the ethnography of communication in which it involves the relationship between language and communication, or the relationship between language and culture. The selected research informants are Jaro from the Baduy community, the people involved in the Seba Baduy Lebak Banten event, who are all research informants are men because only men can be invited to educate and women are prohibited from interacting with the community. outside in the event. And take the informant from someone who works in the government of Lebak regency. The analysis of data in qualitative research was conducted at the time of data collection, and after completion of data collection in a certain period. Basically, in the ethnographic research, the communication process analyzes the data along with the data collection process. The analysis of data on this research is divided into descriptions, analyses and interpretation phases. 


\section{Discussion}

The focus on this research is Seba Baduy communication activity in Lebak Regency of Banten, wherein the implementation it becomes a special activity that appears in each event of Seba Baduy in each of the elements. The communication activity according to Hymes quoted in the communication ethnographic book Engkus Kuswarno, states that typical or complex activities, in which there are special events of communication involving certain actions of communication and in certain contexts (Kuswarno, 2008: 42). The above statement proves that there is a typical communication activity from the Seba Baduy event in which there is a meaning under what the ancestors assigned became an important part of their lives. Likewise, every activity they do aims to honor their ancestors and their way of thanking them to God Almighty. The Seba is a deposit given by their ancestors to stay live until at any time. Seba is also a culture that they believe is their way of thanking the creator and the government. Seba has existed since the Kingdom of Medut of Banten Sultanate. The aim was to have a relationship with the royal family and to thank them because they were guarded and allowed to occupy the kingdom at that time. In the old days, Seba was only done by Jaro-Jaro Tangtu and Dangka. But to preserve Seba's sustainability, it was altered by their ancestors that that did Seba be obliged to follow by the entire Baduy community. The goal is not to be interrupted, and everyone in the Baduy community can do according to the provisions that exist when going to Seba.

Many phases in which they did before doing Seba. The first they harvest what they planted for one year and take a bunch of rice to get in the mashed into the rice. It must be done by every citizen in his home to do the symbolic that their crops have entered the harvest. After they had harvested the crops they planted, they went in droves for self-cleansing or called to purify themselves by the Baduy people in a place they thought was sacred. It cannot be witnessed by people outside the Baduy. They did so because they would do their fasting in the month of Kawalu. Their fasting is for three months in the month of Kawalu Tembe, Kawalu Tengah, and Kawalu Tutung. After they had done the fasting in the month of Kawalu, they did Lebaran in the way of the Ririungan in their respective villages. The Eid is often called the event Kawalu on the Baduy community. Lapse three days after carrying out the Kawalu, Baduy Community Conduct a population census or so-called Ngalaksa, it is done more or less one week of the event. Along with the Ngalaksa Baduy community was ordered to set aside the crops that they could be used as the main requirement in doing Seba. After completion of all activities, then the Baduy community went down to the center of Ciboleger Village to meet Jaro outside and reported that the Baduy community must do Sebada based on Puun provisions in their respective villages. If the specified time is ready, then all Baduy people gathered in the center of Ciboleger Village to do Seba. After Jaro permits departing, Seba has already begun his activity. They are obliged to walk to the place which is the goal of Seba, Lebak Regency, and Banten Province by bearing or carrying some of the crops they get.

\subsection{The communicative situation in The Seba Baduy Event Lebak Regency of Banten}

Based on the results of the research, researchers get 3 situations that researchers can take, the first that Seba should be done after the activities in the Community Baduy completed, namely the activities Kawalu and Ngalaksa. The rules cannot be changed because it has been a predetermined provision since the Seba began in the era of the Kingdom of MEdut or the Sultanate of Banten. For the second situation, a Seba event was done at the turn 
of the year or was on the Safar of the moon's provisions on the Baduy community. The date and time cannot be determined because it should be in the account of Puun for the smoothness and safety of the Baduy people when starting activities until their return to their hometown. Seba was entrusted withal event requesting protection to their ancestors and creators. Because after they had done Seba, they would do a Muja ritual in which it was aimed to convey that they had done what was commanded and thanked what they believed. The third situation that the researcher gets is to problem the place and time where the Seba was done, namely in the City hall Regency Lebak, because it can accommodate the whole Baduy community that follows the event of Seba. The main laden Seba for the problem of the place should have a wide area that can accommodate the whole community Baduy and high government, in order to avoid the difference of caste and flattered between the Baduy community with the government. For the problem of place in Banten province is also in the City hall in the Banten City of Serang. The place is always used as the government to accept the Baduy community in doing Seba. However, the time for the Seba Baduy event cannot be determined, because it depends on the conditions of travel that they experience during the destination or from one place to the next place. But in the last few years that researchers observe, Seba event is done in the afternoon or after Maghrib, as well as the time of activity in the province. So, for the situation in the time category, researchers can only describe that the Seba event took place in the afternoon towards night.

The Interconnectedness of the situation is in the Seba Baduy event of communication theory, the ethnography of communication and the symbolic theory. In relation to communicative situations with interaction, the theory is where the Baduy community symbolized that this Seba event as a symbol that the Baduy community will run the new year in the month HItungan in the community Baduy. As for what makes the Seba event a symbol of Baduy community activity based on what the researchers examined through informant interviews, that is, Seba was symbolized as an event to carry out what their ancestors commanded and to appreciate and be grateful for what the Baduy people got back a year in the government area. In communicative situations, in the event, Seba Baduy There are also elements of communication in it. Whereas in the implementation of Seba Baduy there are communication components namely communicators, messages, communicants, media and effects. This Seba Baduy event conveys the message to the communicants (government) that the Baduy community has carried out the harvest in the government-owned land and they divide the results to the Government through The Baduy's event of Seba, as well as intersecting the owner of the region or government. In the communicative situation, The Baduy's event of Seba, there are also media in the task of conveying to the community outside the regency and Banten province that is the implementation of cultural activities in the province of Banten. For the impact or effect given in the event, Seba only gives a positive effect in which the Baduy community relationship with the government is increasingly harmonious based on what research results researchers are thorough.

The Seba Baduy event is in the tradition of communication ethnography because the event is always repeated at the same time and place until it became a habit of society. The Baduy people always do Seba in the month of Safar from the beginning of Seba. The situation became a benchmark to be done when going to the Seba event. 


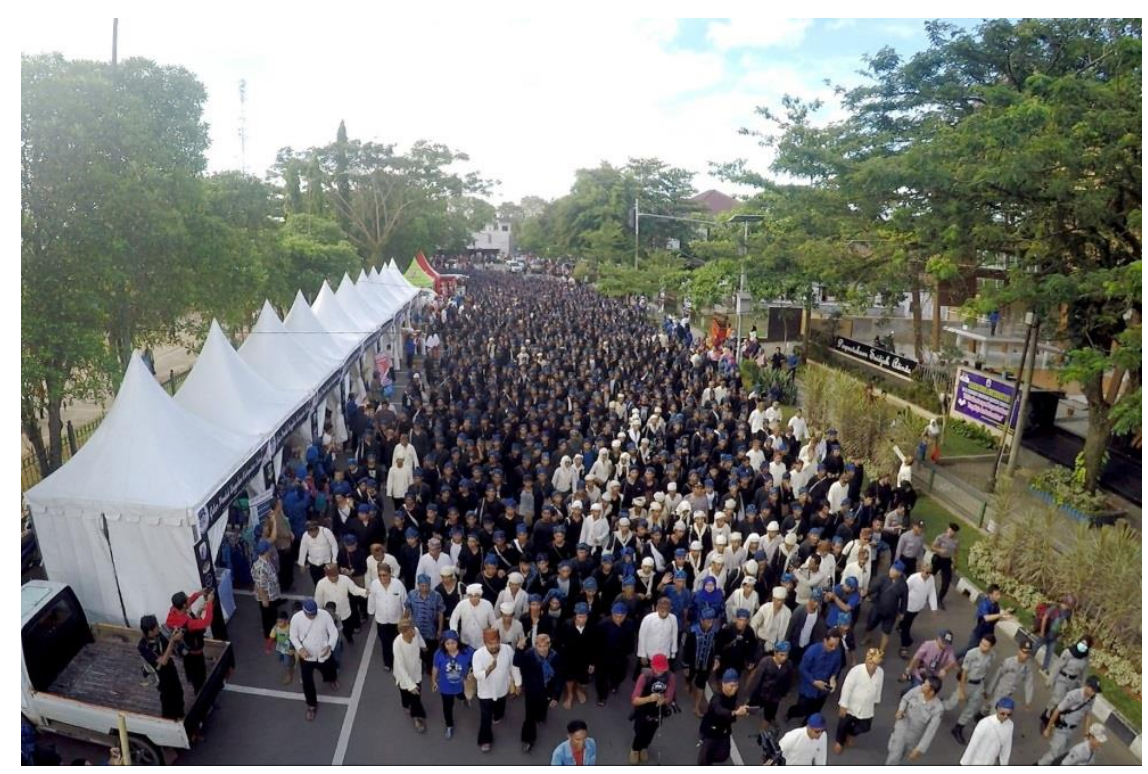

Figure 1. The situation when Seba Goes On

(source: Research Documentation, 2017)

\subsection{Communicative Action in the Seba Baduy event in Lebak Regency, Banten}

Communicative actions in its articles include statements, orders, solicitation \& nonverbal behavior. In the Seba Baduy event, there are some communication measures performed. To find out what non-verbal actions are walking without using a mat and shaking hands after asking permission will enter the government area in the Baduy's event of Seba. The ungrounded footwork is carried out to keep the natural state from being easily damaged due to trampled, as well as the prevailing rules when the Seba is commanded by the Puun. And shaking hands aims to inform the surrounding community and the people of Baduy, that the community of Baduy in allow entry and received either by the government. The Verbal action found in the Seba Baduy event is to say hello to the local government that welcomes the arrival of the Baduy community. This is a symbol when the people of Baduy will enter the regency and provincial government. The purpose of this is to ask permission that the people of Baduy will enter the area of government. Examples of verbal actions that researchers can take while observing directly are:

"assalamuallaikum wr, wb. Neda dihapunten, simkuring bade ngauningakeun katepangkeun babasika sareng rengrengan, yen urang kadongkapan ku dulur urang ti kanekes nu seeurna kirang langkung 2000 jalma, nu maksadna bade ngagendis ka Ibu Bupati, dinalaraga mumule budaya nyaeta nu biasa dilaksanakeun bade Seba Baduy ka ibu gede, ku sakituna mugia di sangga ku pa sekda ti simkuring mangga nyandakeun" (sumber: Data Penelitian 2017)

In communicative action very clearly there are symbols that belong to the communication component through the process of communication done. Communicative action in the Seba event has delivered the message as researchers have explained above. One of them, the verbal action that occurred in the Seba Baduy event during the event is the pronunciation of "greeting" when in front of the gate of the regency or provincial government. It aims to convey the message that they asked for permission to enter the territory of the government. 


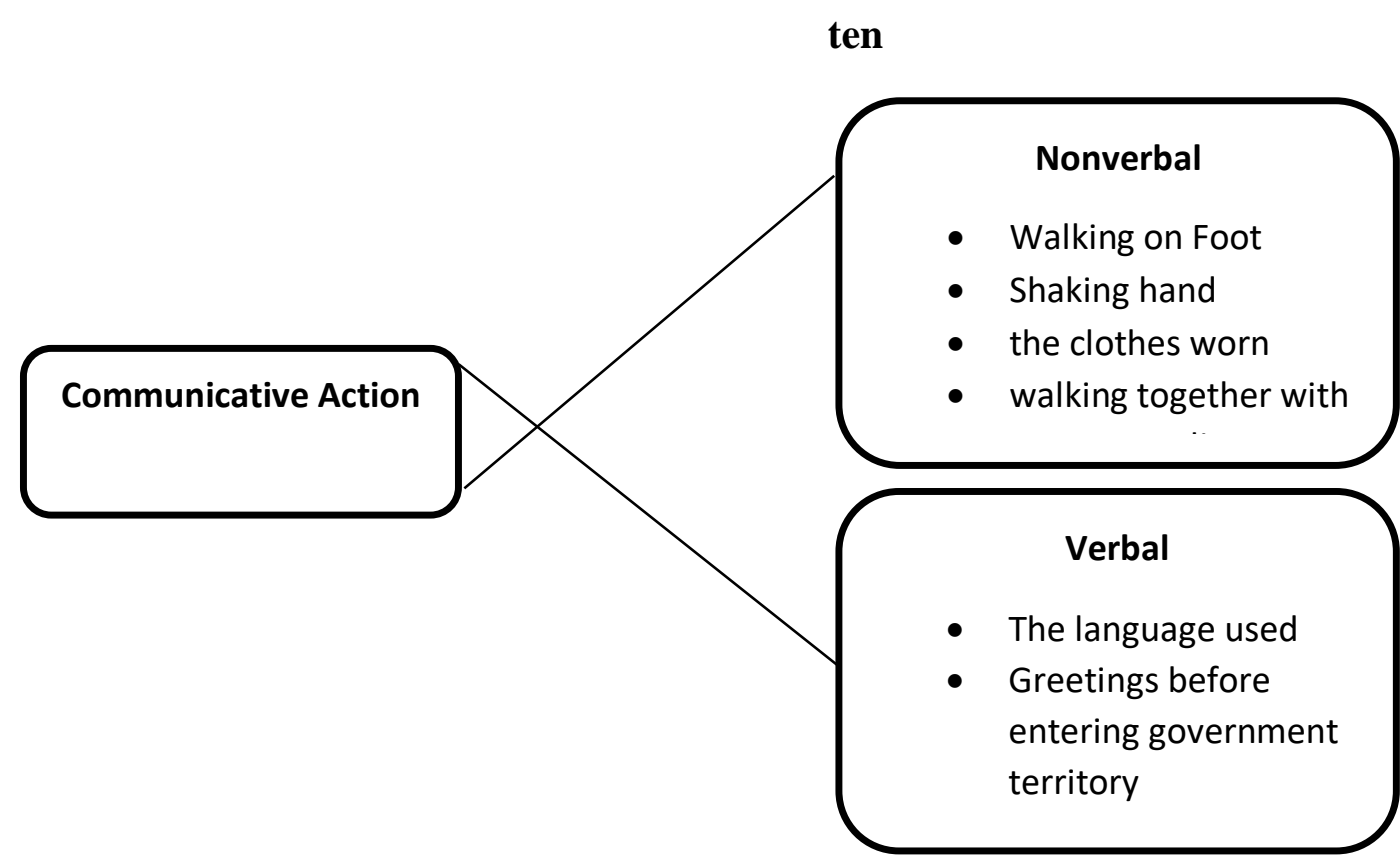

Figure 2. Communicative action in The Seba Baduy event Lebak Regency of Ban (source: Researcher Data, 2017)

Based on observation results conducted by researchers about the situation, events and actions in The Baduy's event of Seba, researchers saw that the event was merely done to provide gratitude for the crops they get to God Almighty. The event as a way they do to thank and give thanks to the God Almighty so that the crops they get blessings and are always added or harvested the following year more from the crops they get today. There are many things that researchers observe based on the sub-focus on the researchers' reference contained in the Seba Baduy event communication activities, so it can be concluded that everything that is done from the Seba Baduy event is based on observations and interviews, namely as a way carried out by the Baduy community to be grateful for everything they have got from the harvest they have got, and do not forget to thank the government for being allowed to occupy the area they occupy.

\section{Conclusion}

The Seba Baduy event was done after several preparations in the activities of the Baduy community. The preparation to implement Seba is that the Baduy community must conduct self-cleansing or purify themselves while fasting in the month of Kawalu and Ngalaksa as well as collecting crops that have been set aside for Seba activities. After all, preparations were made, the Baduy community would descend the mountain based on the time prescribed by the Puun. For this year, Seba was conducted from 19 to 22 May 2017. The Baduy Seba community calendar is performed in the month of Safar of the year of the welcome month. There is a place that they are headed to run Seba, the City hall Lebak Regency on May 20, 2017, and the City hall governor dated May 21, 2017. For the duration of the Seba, it cannot be clearly determined, but it is done in the afternoon to the evening.

The communicative event in Seba Baduy event is where Seba has 2 places, namely regency city hall and province city hall. Seba was attended by Jaro, Jaro Tangtu and Dangka, 
Baduy people and government in Seba's activities. Before committing Seba, Baduy people did some preparations in the series of Seba, including Kawalu, Ngalaksa, and gathered crops. His purpose was to have Seba according to what their ancestors had done. While the purpose of Seba itself is how they thank and thank the government and offer gratitude to God Almighty for the crops they get. The contents of the message are grateful to God Almighty and live the commandment given by the ancestors of the Baduy community. The form of message in The Seba Baduy event is to keep the friendship and thank the government and to unite with nature to be guarded. They do it by giving crops and walking to the designated place. But in the event of Seba, there are rules and prohibitions to be asserted. The rules are the determination of the date and place and the ordinances commanded by their Puun. For the prohibition, Baduy people who are doing Seba must not use public transportation to the destination and are forbidden to joke in Seba. Seba belongs to the type of story event. The actions of communication contained in the Seba Baduy event are two types of action, namely Verbal and Nonverbal. In general, for verbal, the Baduy community led by Jaro greeting the greetings when in front of the gates of the government that was welcomed by local officials. While the nonverbal event of Seba is walking their feet to the place that they headed in the event of Seba and shaking handshake between the representatives of the Baduy community with representatives from the Government, that the Baduy community is welcome to enter the region of government.

\section{References}

Alo liliweri, 2011. Komunikasi Serba Ada Serba Makna, Prenada Media Group, Jakarta Bungin, Burham. 2007. Penelitian Kualitatif. Jakarta: Kencana.

Creswell, John W. 2010. Research Design Pendekatan Kualitatif, Kuantitatif, dan Mixed. Yogyakarta: Pustaka Pelajar.

Effendy, Onong Uchjana. 1993, Human Relation dan Public Relation, Bandung: Mandar Maju

Rosdakarya. 2004, Ilmu Komunikasi: Teori dan Praktek. Bandung: PT Remaja

Hasbullah. (2018). Communication Pattern of Wilayatul Hisbah, Lhokseumawe City

in Implementing Amar Makruf Nahi Mungkar. Budapest International Research and Critics Institute (BIRCI-Journal), 194-205.

Kuswarno, Engkus. 2008. Etnografi Komunikasi: Suatu Pengantar dan Contoh Penelitiannya. Bandung: Widya Padjajaran.

Moleong, Lexy. J. 2007. Metode Penelitian Kualitatif. Bandung: PT. Remaja Rosda Karya Mulyana, Deddy. 2007. Ilmu Komunikasi Suatu Pengantar. Bandung. PT. Remaja Rosda Karya

2010. Komunikasi Antar Budaya. Bandung: PT. Remaja Rosdakarya.

Sendjaja, Djuarsa, 2004. Pengantar Ilmu Komunikasi. Jakarta: PT. Raja Grafindo Persada Sugiyono. 2012. Memahami Penelitian Kualitatif. Bandung: Alfabeta.

Sumber Lain:

http://indonesiaindonesia.com/f/91943-suku-Baduy/ (tanggal: 4 mei 2017 jam: 20.30 wib) 